Global Spillovers into Domestic Bond Markets

in Emerging Market Economies 


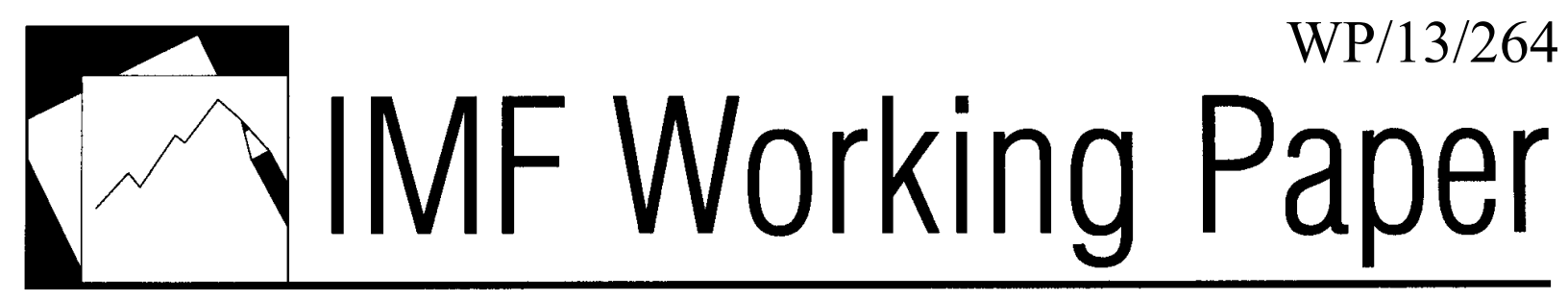

\title{
Global Spillovers into Domestic Bond Markets in Emerging Market Economies
}

\author{
Laura Jaramillo and Anke Weber
}




\title{
IMF Working Paper
}

Fiscal Affairs Department

\section{Global Spillovers into Domestic Bond Markets in Emerging Market Economies*}

Prepared by Laura Jaramillo and Anke Weber

Authorized for distribution by Julio Escolano

December 2013

\section{This Working Paper should not be reported as representing the views of the IMF. The views expressed in this Working Paper are those of the author(s) and do not necessarily represent those of the IMF or IMF policy. Working Papers describe research in progress by the author(s) and are published to elicit comments and to further debate.}

\begin{abstract}
While fiscal conditions remain healthier than in advanced economies, emerging economies continue to be exposed to negative spillovers if global conditions were to become less favorable. This paper finds that domestic bond yields in emerging economies are heavily influenced by two international factors: global risk appetite and global liquidity. Using a novel approach, the analysis goes on to show that the vulnerability of emerging economies to these factors is not uniform but rather depends on country specific characteristics, namely fiscal fundamentals, financial sector openness and the external current account balance.
\end{abstract}

JEL Classification Numbers: E44, E62, G15, H63, O16.

Keywords: Bond Markets, Emerging Market Economies, Fiscal Deficit, Public Debt, Global Spillovers

Author’s E-Mail Address:ljaramillomayor@imf.org; aweber@imf.org

\footnotetext{
* We thank Carlo Cottarelli, Phil Gerson, Martine Guerguil and Andrea Schaechter for helpful comments and discussions. We are grateful for comments by, Nina Budina, Carlos Caceres, Salvatore Dell'Erba, Anna Ivanova, Manmohan Kumar, Tigran Poghosyan, Dominique Raelison, Daniel Rodriguez and Yan Sun. We would like to thank the Economist Intelligence Unit and in particular Michael Schaeffer for providing data on market expectations of fiscal variables, inflation and growth. Petra Dacheva and Raquel Gomez-Sirera provided excellent research assistance. All remaining errors are our own.
} 


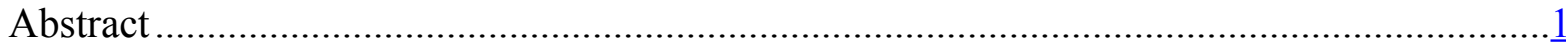

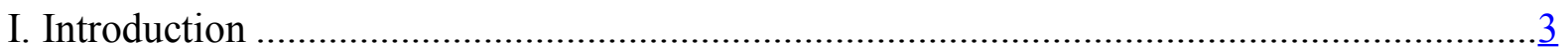

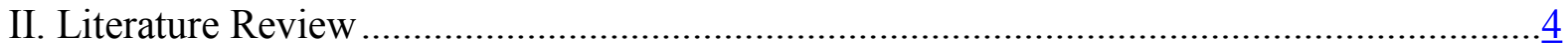

III. Recent Developments in Domestic Sovereign Bond Markets ......................................

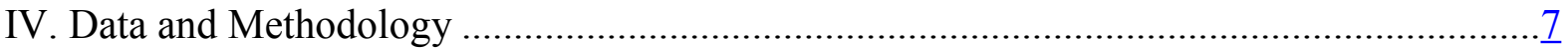

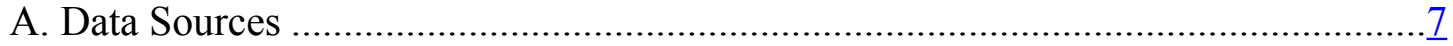

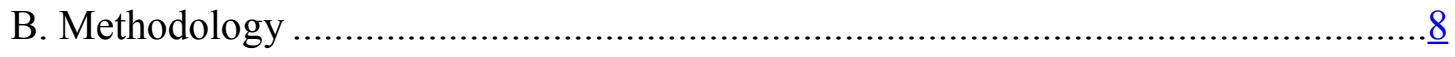

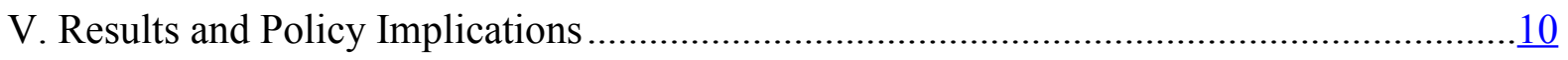

VI. Summary and Conclusions …......................................................................... 14

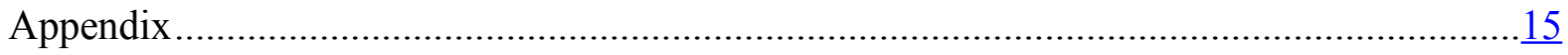

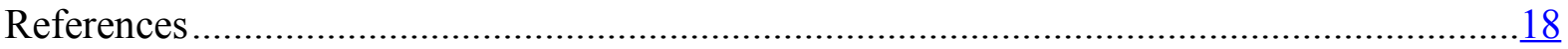

Tables

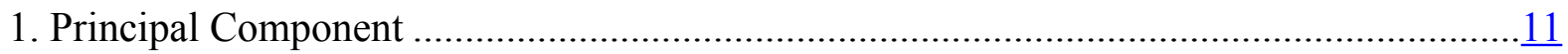

2. Correlations with Common Factors …...................................................................12

3. Determinants of 10-year Domestic Bond Yields in Emerging Economies ........................12

Figures

1. Primary Balance and Debt Stablizing Primary Balance, 2012 .......................................... $\underline{3}$

2. Sovereign Domestic Bond Yields ....................................................................... $\frac{7}{7}$

3. Sovereign Domestic Bond Yields and Global Risk Aversion ........................................

4. Sovereign Domestic Bond Yields and Global Liquidity ............................................. 1

5. Sovereign Domestic Bond Yields by Region ......................................................... 7

6. Emerging Economies: Global Factors, Fiscal Indicators, Financial Openness, and External Current Account Deficit 


\section{INTRODUCTION}

In recent years, financing conditions in most emerging market economies have remained relatively stable, in the context of low global interest rates and low global risk appetite. Indeed, domestic bond yields across emerging market economies at end-2012 were lower than they were in 2006. Nonetheless, even under these relatively benign financing conditions, several countries, including some with relatively high debt to GDP ratios, are running primary balances that are insufficiently high to stabilize debt and some others are only within a small margin (Figure 1). This raises the question: how vulnerable are emerging economies if global conditions were to become less favorable?

This paper addresses this question by identifying the global factors that are most likely to impact on domestic bond markets of emerging market economies, extending the work in Jaramillo and Weber (2013). It also explores the possibility that the

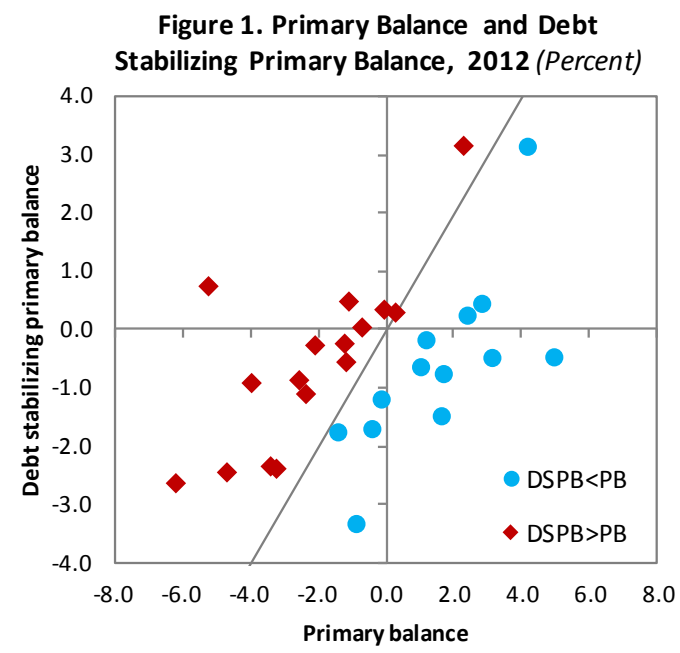

Sources: IMF Fiscal Monitor, and authors' estimates. Note: Debt stabilizing primary balance (DSPB) is the primary balance (PB) that would stabilize debt at 2011 levels, based on the interest rate growth differential of vulnerability to global movements is not uniform but rather depends on country specific characteristics. First, a factor-augmented panel estimation-based on a monthly dataset for 26 emerging economies between 2007 and 2013 - identifies the common factors that affect domestic bond yields in all countries, controlling for other country specific conditions such as expected fiscal deficits and debt, inflation, and growth. These underlying factors are found to be associated with global risk appetite ${ }^{2}$ (proxied by the VIX ${ }^{3}$ ) and global liquidity (proxied by one-year ahead market expectations of 3 month U.S. interest rates ${ }^{4}$ ). Second, the model is recalculated to include the VIX and expected U.S. short-term interest rates as explanatory variables, and shows that their impact on financing costs varies across countries. Specifically, the coefficient on the VIX for each country is found to be closely linked to the strength of its

\footnotetext{
${ }^{2}$ Risk appetite - the willingness of investors to bear risk - depends on both the degree to which investors dislike uncertainty (risk aversion) and the level of that uncertainty. Risk aversion is part of the intrinsic makeup of investors, is unlikely to change markedly, or frequently, over time. Risk appetite, by contrast, is likely to shift periodically as investors respond to episodes of financial distress and macroeconomic uncertainty. In adverse circumstances, investors will require higher excess expected returns to hold each unit of risk and risk appetite will be low (see Gai and Vause, 2006).

${ }^{3}$ The Chicago Board Options Exchange Volatility Index (VIX) is a measure of the market's expectation of stock-market volatility over the next 30-day period. It is a weighted blend of prices for a range of options on the S\&P 500 index. See http://www.cboe.com/micro/VIX/vixintro.aspx.

${ }^{4}$ Global liquidity can be defined in a number of ways. Here we use short-term interest rates as a price indicator that conveys information about the conditions at which liquidity is provided. See Bank for International Settlements (2011).
} 
fiscal position and financial sector openness, as countries with weaker fiscal fundamentals and greater nonresident participation in their local bond markets would consequently be more susceptible if global markets suddenly retreat to safe-havens. Meanwhile the global liquidity coefficient for each country is found to be closely linked to its external current account balance, as countries with greater public and private sector reliance on external financing would be faced with a sudden shortfall in available resources if global liquidity conditions tightened. To the best of our knowledge, this paper is the first one to apply a factoraugmented panel estimation in this particular context, estimating emerging economy country specific responses to global shocks.

The remainder of this paper is structured as follows. Section II reviews the existing literature on the determinants of domestic bond yields in emerging markets. Section III discusses recent developments in domestic sovereign bond markets. Section IV provides background on the estimation methodology while Section V provides details on data and estimation results. Section VI presents the main conclusions and policy implications.

\section{LiterATURE REVIEW}

In contrast to widespread studies on sovereign foreing currency spreads, few papers have focused on emerging market domestic sovereign bonds, notwithstanding their growing relevance as a source of government financing. ${ }^{56}$ Peiris (2010) conducts a panel analysis of 10 emerging market economies and finds that both domestic macro and global factors have a significant influence on long-term local currency government bond yields in emerging market economies, namely the fiscal balance, changes in policy interest rates, inflationary expectations, and foreign participation in domestic bond markets. Baldacci and Kumar (2010) estimate a panel of 31 advanced and emerging economies over the period 1980-2007 and find that higher deficits and public debt lead to a significant increase in long-term interest rates, with the precise magnitude dependent on initial fiscal, institutional and other structural conditions, as well as spillovers from global financial markets. Miyajima and others (2012) show that domestic factors, including expectations of the short-term interest rates and the fiscal balance, have tended to dictate the dynamics of the emerging market local currency government yield.

Meanwhile, the effect of global factors on financing costs in emerging economies has hitherto typically been analyzed within the context of the literature on the determinants of sovereign foreign currency spreads. McGuire and Schrijvers (2003) find that global risk

\footnotetext{
${ }^{5}$ Studies using sovereign foreign currency spreads are more widespread. Many empirical studies have focused on the impact of domestic factors, including indicators of external vulnerability like external debt, debt service or current account (Edwards, 1984; Cantor and Packer, 1996); fiscal variables, like fiscal debt and deficits (Cantor and Packer, 1996; Rowland and Torres, 2004; Vargas, Gonzalez and Lozano, 2012) or their composition (Akitoby and Stratmann, 2008); and other macroeconomic variables like inflation, the terms of trade and the real exchange rate (Min, 1998).

${ }^{6}$ See Mihaljek and others (2002), Bank for International Settlements (2007) and Burger and others (2010) for a discussion of the development of domestic sovereign debt markets in emerging market economies.
} 
appetite is a significant factor driving spreads, while Eichengreen and Mody (2000) and Bellas and others (2010) show that changes in market sentiment affect spreads. GonzalesRosada and Levy-Yeyati (2008) find that in addition to global risk appetite, global liquidity plays a central role. Hartelius and others (2008) and Dailami and others (2008) provide similar results when looking at U.S. interest rates. Longstaff and others (2011) look at CDS spreads in 26 advanced and developing countries and find that the majority of sovereign credit risk can be linked U.S. stock market returns and the VIX index. Pan and Singleton (2008) also document a similar strong relation between CDS spreads and the VIX index for Turkey, Korea and Mexico. For domestic bond yields, Baldacci and Kumar (2010) find that in periods of financial distress - defined as periods of high levels of the VIX index, high inflationary pressures, and more adverse global liquidity conditions-fiscal deterioration has a larger impact on bond yields. Jaramillo and Weber (2013) show that, when global risk appetite is low, domestic bond yields are mostly influenced by inflation and real GDP growth expectations, suggesting that, in tranquil times, markets focus more prominently on risk stemming from sensitivity to macroeconomic shocks. However, when global risk appetite is high, creditors' concern with default risk takes center stage and expectations regarding fiscal deficits and government debt play a significant role in determining domestic bond yields.

The paper more closely related to our work but focusing on advanced rather than emerging economies is Dell'Erba and Sola (2011). Dell'Erba and Sola (2011) estimate the effect of fiscal policy on long-term interest rates for a panel of 17 OECD countries. They investigate the determinants of long-term bond yields within a factor augmented panel to control for the presence of unobserved common factors. They find that two global factors (the global monetary and fiscal policy stances) explain more than 60 percent of the variance in long-term interest rates. Moreover, they go on to show that large economies and economies characterized by low financial integration and current account deficits are less prone to the propagation of those common shocks. ${ }^{7}$

\section{RECEnt DEVElopMents In DoMestic SOVEREIGN Bond MARKETS}

In recent years, sovereign domestic bond yields remained relatively stable for the median emerging economy. Though domestic sovereign bond yields increased in the aftermath of the Lehman collapse, by 2011 bond yields had fallen below their 2006 levels (Figure 2). However, this masks considerable volatility for a number of countries. Figure 2 also shows the distribution of bond yields across emerging economies. The financial crisis brought a considerable amount of differentiation across countries, with interest rates jumping to double digits in some cases. While this differentiation has since narrowed, the distance between countries did not return to its pre-crisis margin, suggesting greater market discrimination across emerging market countries.

\footnotetext{
${ }^{7}$ Sgherri and Zoli (2009), McGuire and Schrijvers (2003), and Longstaff (2011) have used common factor analysis to explain sovereign spread movements in advanced and emerging market economies.
} 
Part of this greater differentiation appears to be linked to global factors, in particular international investors' appetite for risk and expectations about global liquidity. In recent years, the standard deviation across domestic bond yields in emerging economies has increased with upward movements in global risk appetite, as proxied by the VIX (Figure 3). ${ }^{8}$

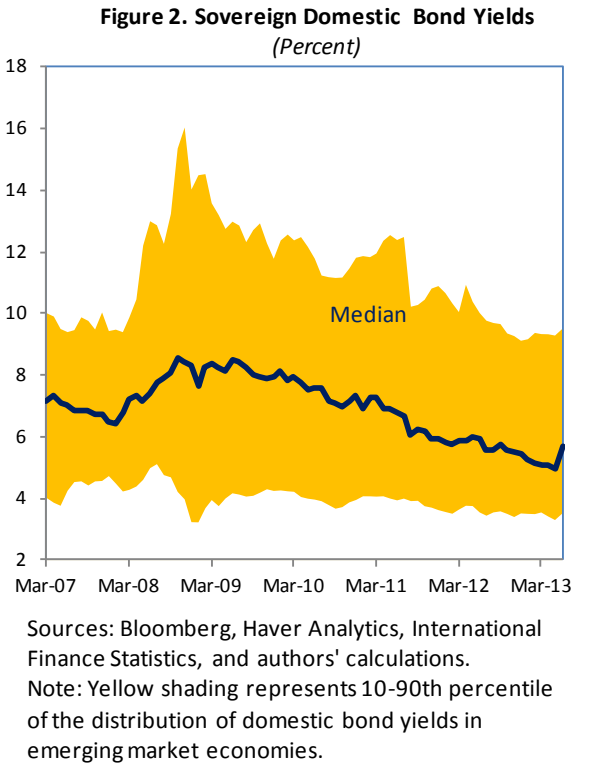

Similarly, global liquidity, proxied by one-year ahead market expectations of 3 month U.S. interest rates, also appears to be playing a role (Figure 4). Although in some cases nonresident holdings of government debt are relatively small (for example China and India), private investors from emerging market economies are increasingly putting their funds in overseas assets (Karolyi and others, 2013), therefore global liquidity and risk appetite would affect residents' decisions to invest abroad to the extent that they impact their risk-return tradeoff.

Furthermore, sovereign bond yields have not behaved uniformily across different regions, as shown in Figure 5. European emerging market economies showed much larger changes in sovereign bond yields since the onset of the global financial crisis compared to other emerging market economies. In constrast, bond yields

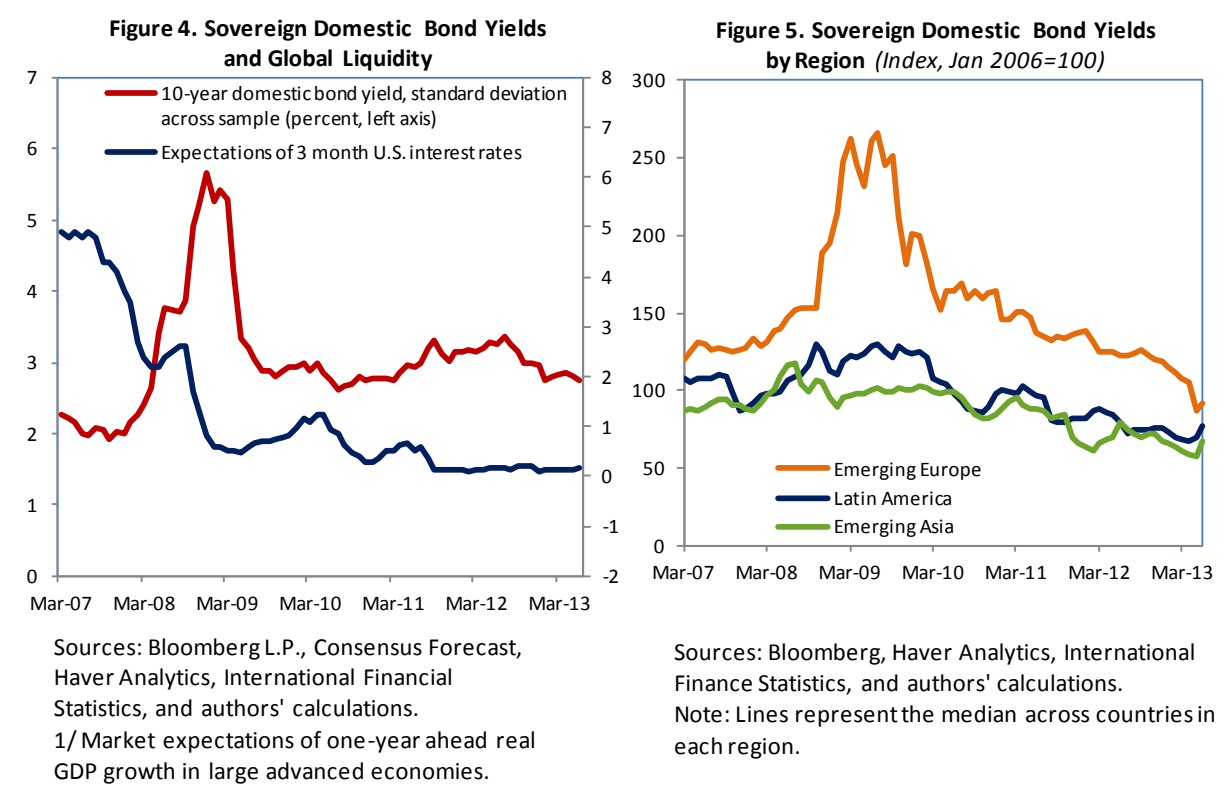

\footnotetext{
${ }^{8}$ The VIX has been traditionally used in the literature as measure of global risk appetite. See for example McGuire and Schrijvers (2003), IMF (2004), Gonzales-Rozada and Levy-Yeyati (2008), Hartelius and others (2008), Bellas and others (2010), Baldacci and Kumar (2010), and Longstaff and others (2011).
} 
for emerging markets in Asia remained relatively more stable over the same period. This suggests that particular characteristics of these economies may have increased or decreased their vulnerability to external shocks.

\section{DAta And Methodology}

\section{A. Data Sources}

We construct a panel dataset of monthly observations for 26 emerging economies between January 2005 and July 2013. This dataset was originally developed by Jaramillo and Weber (2013). The novelty is that this dataset contains one-year ahead market expectations for annual inflation, real GDP growth, the fiscal balance to GDP ratio, and public debt to GDP ratio, whose source is the Economic Intelligence Unit (EIU). The forecasts provided by the EIU are produced by in-house analysts who employ spreadsheet-based models, using a framework that is carefully customized for each individual economy and structured to ensure internal consistency. Forecasts are provided for the current year as well as one to five years ahead, and are updated once a month. ${ }^{9}$

The dataset also includes long-term (typically 10-year) domestic bond yields, the domestic Treasury bill rate and money market rates obtained from Bloomberg, Haver, and International Financial Statistics. To capture global liquidity conditions, the one-year ahead market expectations of 3-month U.S. interest rates is included, obtained from Consensus Forecast. The VIX is used as a proxy for global risk appetite, obtained from Bloomberg. Additional market expectations of growth, inflation, and budget deficits, obtained from Consensus Economics, were used when performing the robustness checks, though the fiscal data are only available for a small group of countries. The Appendix provides more details on data sources by country.

The criterion that determined the inclusion of countries in the panel was data availability of long-term domestic bond yields and the one-year ahead expectations of public debt to GDP. Data on long-term domestic bond yields are only available over a long enough time span for a selected number of emerging economies. We decided only to include countries for which at least data for 12 months without gaps on long-term domestic bond-yields were available. This was the case for 26 emerging market economies. As shown in the Appendix, the data coverage for the countries in our sample differs. For some of those countries, data on these variables since 2005 are available. For others, observations only start in 2008 or 2009. For a number of countries, several sources for long-term bond yields were available. In these cases, we checked consistency of data across these different sources. Data on the one-year ahead expectations of public debt to GDP from EIU are only available from March 2007.

\footnotetext{
${ }^{9}$ For example, in January 2005, the EIU would provide a forecast for annual inflation in 2006. This would then be updated in February 2005, March 2005 and each consecutive month until December 2005. All twelve monthly forecasts made in 2005 for annual inflation in 2006 will be included in our estimations as measuring the expected inflation in $\mathrm{t}+1$.
} 


\section{B. Methodology}

We follow Dell'Erba and Sola (2011) and Giannone and Lenza (2008) in their approaches and estimate a factor augmented panel that allows for heterogeneous effects of common factors across countries. The factor-augmented panel estimation-based on a monthly dataset for 26 emerging economies between March 2007 and July 2013-first identifies the common factors that affect domestic bond yields in all countries, controlling for other country specific conditions such as expected fiscal deficits and debt to GDP ratios, inflation, and real GDP growth. Second, we analyze which variables are associated with those common factors.

Third, the model is recalculated to include those variables that are closely associated with the common factors as explanatory variables, and allows their impact on domestic bond yields to vary across countries. This section will first outline the basic model that has traditionally been use to investigate domestic bond yields and then specify how it is extended to a factor augmented panel.

\section{The standard econometric specification}

The standard methodology used for advanced economies (see for example, Reinhart and Sack, 2000), estimates the following fixed effects panel data model:

$r_{i t}=\alpha_{i}+\beta^{\prime} x_{i t}+\varepsilon_{i t}$

where $r_{i t}$ denotes nominal yields on the long term domestic bond yields for country $i$ $(\mathrm{i}=1, \ldots, \mathrm{N} ; \mathrm{t}=1, \ldots, \mathrm{T})$ and $\mathrm{x}_{\mathrm{it}}$ is a vector of explanatory variables, which includes macroeconomic and fiscal variables for $(i=1, \ldots, N ; t=1, \ldots, T)$.

Some heterogeneity between countries is allowed by introducing time-invariant country characteristics in the form of fixed effects $\left(\alpha_{i}\right)$. There are many institutional peculiarities in domestic bond markets that are country specific. For example, financial markets in emerging economies are still developing in many cases, which could affect the overall liquidity of the bond market (e.g. market size, turnover). Also, financial repression has been experienced in the past in some countries, helping to keep interest rates low. It is expected that fixed effects would control for these institutional issues, in particular given the relatively short and recent time frame discussed in the paper and the gradual process that is typically involved in institutional change.

In choosing which explanatory variables to use in the estimation of equation (1), we follow the literature on domestic bond yields in advanced economies that has typically included fiscal variables (public debt and the fiscal deficit to GDP) as well as real GDP growth and inflation as explanatory variables. Following Laubach (2009), and in order to avoid potential endogeneity issues, we use market expectations of the fiscal variables, real GDP growth and inflation. ${ }^{10} \mathrm{We}$ also include a measure of the short-term nominal interest rate to control for

\footnotetext{
${ }^{10}$ We follow the recent literature (e.g. Laubach, 2009) and include expectations of both the fiscal deficit and public debt. It should be noted that due to stock flow adjustments there can be significant differences between the change in the public debt and the fiscal deficit. Stock flow adjustments, which arise for different reasons
}

(continued...) 
the effects of monetary policy on the term structure.

\section{Estimating a Factor-Augmented Panel}

One potential shortcoming of the above specification is that it is likely that in open and integrated economies, $\mathrm{r}_{\mathrm{it}}$ and $\mathrm{x}_{\mathrm{it}}$ are influenced by the same common shocks such as business cycle fluctuations. This would give rise to so-called cross sectional dependence, which implies that the error terms are correlated across countries since the units of observations are simultaneously affected by common but unobserved factors. Such cross-sectional dependence leads to inefficient estimates and the literature has identified several methods to correct for it (Pesaran, 2004, 2006). These include using so-called common correlated effects estimators (Pesaran, 2006) or a factor augmented panel, which extracts principal comments from observable variables and then explicitly includes those global factors into the regressions (Giannone and Lenza, 2008). In this paper, we decided to use the latter

methodology since this allows us to focus on the underlying global factors and match them to actual variables, whose impact on different emerging economies can then be investigated.

Following Dell'Erba and Sola (2011), we can impose the following factor structure:

$\left\{\begin{array}{l}r_{i t}=\sum_{j=1}^{k} \gamma_{j i}^{r} f_{j t}+r_{i t}^{I D} \\ x_{i t}=\sum_{j=1}^{k} \gamma_{j i}^{X} f_{j t}+x_{i t}^{I D}\end{array}\right.$

Equation (2) specifies that the observable variables, $\mathrm{r}_{\mathrm{it}}$ and $\mathrm{x}_{\mathrm{it}}$ are a combination of $\mathrm{k}$ unobservable global factors and an idiosyncratic component, which is unaffected by global shocks.

Ideally, we would like to estimate equation (1) with the idiosyncratic components only:

$r_{i t}^{I D}=\alpha_{i}+\beta^{\prime} x_{i t}^{I D}+u_{i t}$

However, since the common shocks are unobserved, this implies that the idiosyncratic components are also not directly observable. Using (2) we can rewrite equation (3) in terms of observable quantities and global factors:

$$
r_{i t}=\alpha_{i}+\sum_{j=1}^{k}\left(\gamma_{j i}^{r}-\beta^{\prime} \gamma_{j i}^{X}\right) f_{j t}+\beta^{\prime} x_{i t}+u_{i t}
$$

Equation (4) now takes explicitly account the common factors and if they can be consistently estimated, then (4) can be estimated by standard panel techniques (Dell'Erba and Sola, 2011). In order to obtain consistent estimates of the unobservable factors, a principal components technique is used following Giannone and Lenza (2008) and Dell'Erba and

including valuation effects, have been found to be the largest source of major debt increases in emerging economies over the past three decades (Weber, 2012). 
Sola (2011).

The principal components analysis (PCA) involves collecting all dependent and independent variables for each country in a matrix, $\mathrm{P}$, which will then have the dimension $\mathrm{T}^{*}(\mathrm{~N}(\mathrm{~m}+1))$ where $\mathrm{N}$ denotes the number of countries included in the estimation, $\mathrm{T}$ denotes the number of time series observations, and $\mathrm{m}$ the number of explanatory variables, which include the fiscal variables. The PCA extracts the eigenvectors of this matrix obtained from the eigenvalueeigenvector decomposition of the covariance matrix of $\mathrm{P}$. The eigenvectors are linear combinations of the columns of $\mathrm{P}$ and if the common factors are pervasive whereas idiosyncratic shocks are not, they are consistent estimates of the set of common factors (for more details on this see Dell'Erba and Sola, 2011). Given the dimensions of P, there are $\mathrm{N}(\mathrm{m}+1)$ eigenvectors. We will not use all of them in our estimations, but keep as many common factors as are needed to ensure that we can explain at least 60 percent of the panel variance. This ensures that we choose those factors which explain most of the correlations among our data.

We can then rewrite (4) as follows:

$r_{i t}=\alpha_{i}+\beta^{\prime} x_{i t}+\delta_{1 i} \hat{f}_{1 t}+\delta_{2 i} \hat{f}_{2 t} \ldots+\hat{f}_{q t}+u_{i t}$

Where $\mathrm{q}$ denotes the number of factors that are included to ensure that at least 60 percent of the panel variance is explained by the common factors. While this specification allows for heterogeneous effects of common factors cross countries, it assumes that the coefficient $\beta$ is the same for all countries, in order to ensure consistency with previous studies and also limit the number of coefficients that have to be estimated.

Our estimation strategy in this paper is to match those common factors that explain most of the panel variance to actual variables, include those in the specification outlined in equation (5) instead of the common factors and then to analyze whether the effects of those global shocks on long-term interest rates are the same across emerging economies. This is followed by a correlation analysis of which domestic factors could explain possible differences across countries.

\section{Results ANd Policy Implications}

The principal components analysis suggests that movements in sovereign bond yields in emerging market economies are driven largely by two underlying common factors (Table 1). ${ }^{11}$ The first two eigenvectors explain 66 percent of the panel variance. A scree plot of eigenvalues suggests either 2 or 4 factors due to the way the slope levels off twice (Figure 6). ${ }^{12}$ We choose to retain two factors in order to balance parsimony (a model with

\footnotetext{
${ }^{11}$ The principal components analysis is performed using STATA. STATA uses an orthogonal rotation method as the default option.
} 
few factors) with plausibility (explaining most of the variability in the variables). The reason for not including more factors is that we want to limit the number of coefficients that have to be estimated.

Figure 6. Screen plot of Eigenvalues after the Principal Components Analysis

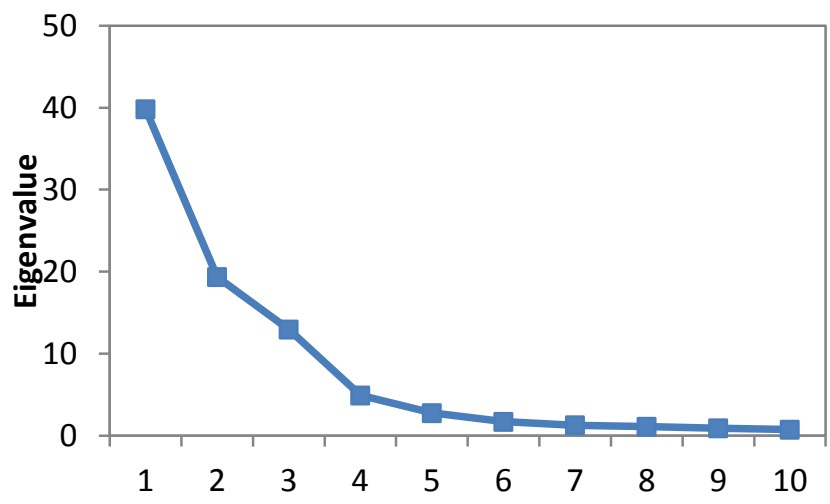

Table 1. Principal Components

\begin{tabular}{l|lllll}
\hline & $1 s t$ & $2 n d$ & & 4 th & 5th \\
\hline Marginal & 0.44 & 0.22 & 0.14 & 0.05 & 0.03 \\
Cumulative & 0.44 & 0.66 & 0.80 & 0.86 & 0.89 \\
\hline
\end{tabular}

Note: The table reports the marginal and cumulative proportions of the explained variance by the first 5 principal components.

In order to find an economically meaningful interpretation of the two common factors, the paper analyzes the simple correlation between each common factor and variables that reflect global trends, with particular focus on series that capture developments in the global economy and changes in the willingness of investors to incur risk. While it is impossible to identify precisely what the common factors represent, this exercise proves useful in determining which global trends tend to be the most important. The expected 3-month interest rates in the U.S., the Federal funds rate, and expected 10-year U.S. bond yield, are used as measures of global liquidity. The VIX, the BBB corporate spread, and the high-yield spread are used as measures of investor risk tolerance. Table 2 shows that the common factors are significantly correlated with several of these variables. This result is driven both by the high correlation between many of these variables themselves and by the fact that the common factor, by construction, represents a mixture of all common forces driving emerging market sovereign yields. Overall, the analysis indicates clear correlation between the first common factor and global liquidity (as measured by market expectations of 3 month US interest rates), and also a strong correlation between the second common factor and the VIX.

\footnotetext{
${ }^{12}$ The Kaiser criterion, which drops all factors with an eigenvalue of less than one, would have resulted in 8 common factors. However, we do not follow this criterion here since it tends to overextract factors (Bandalos and others, 2008). Indeed, there is a consensus in the literature that it is one of the least accurate methods for selecting the number of factors to retain (Velicer and Jackson, 1990).
} 
To note, global liquidity and global risk appetite are also likely to be interrelated through different leads and lags. Short-term interest rates could react to movements in equity prices reflecting the expected endogenous response of monetary policy to the impact of stock price movements on aggregate demand (Rigobon and Sack, 2003). Similarly, a change in shortterm interest rates could impact the VIX through changes in the aggregate balance sheet of the financial intermediaries (Shin and Adrian, 2010).

Table 2. Correlations with Common Factors

\begin{tabular}{lrr}
\hline & $\begin{array}{c}\text { Common } \\
\text { factor 1 }\end{array}$ & $\begin{array}{c}\text { Common } \\
\text { factor 2 }\end{array}$ \\
\hline Measures of global liquidity & & \\
Expected U.S. 3 month interest rate & 0.78 & -0.31 \\
Federal funds rate & 0.74 & -0.31 \\
Expected U.S 10-year bond yield & 0.51 & -0.37 \\
Measures of global risk appetite & & \\
VIX & -0.06 & 0.84 \\
BBB corporate spread & -0.02 & 0.84 \\
High-yield spread & -0.18 & 0.83 \\
\hline
\end{tabular}

Sources: Bloomberg L.P., Haver Analytics, Consensus Forecasts and authors' estimates.

The model is then estimated first without the common factors as in column 1 and then including the VIX and the expected U.S. short-term interest rate as additional explanatory variables in column 2 (as in equation 5). The results are shown in Table 3:

Table 3. Determinants of 10-year Domestic Bond Yields in Emerging Economies

\begin{tabular}{|c|c|c|c|c|}
\hline \multirow{3}{*}{ Expected gross debt $\mathrm{t}+1$ (percent of GDP) } & \multicolumn{2}{|c|}{ [1] } & \multicolumn{2}{|l|}{ [2] } \\
\hline & 0.05 & $* * *$ & 0.04 & *** \\
\hline & $(0.01)$ & & $(0.01)$ & \\
\hline \multirow[t]{2}{*}{ Expected overall balance $\mathrm{t}+1$ (percent of GDP) } & -0.27 & $* * *$ & -0.38 & $* * *$ \\
\hline & $(0.03)$ & & $(0.03)$ & \\
\hline \multirow[t]{2}{*}{ Expected inflation rate $\mathrm{t}+1$ (percent) } & 0.01 & & 0.07 & ** \\
\hline & $(0.02)$ & & $(0.03)$ & \\
\hline \multirow[t]{2}{*}{ Expected real GDP growth rate $\mathrm{t}+1$ (percent) } & 0.00 & & 0.02 & \\
\hline & $(0.03)$ & & $(0.03)$ & \\
\hline \multirow[t]{2}{*}{ Domestic Treasury bill rate (percent) } & 0.71 & $* * *$ & 0.71 & *** \\
\hline & $(0.02)$ & & $(0.02)$ & \\
\hline \multirow[t]{2}{*}{ Constant } & 0.05 & & 0.10 & \\
\hline & $(0.3)$ & & $(0.37)$ & \\
\hline Number of observations & 1066 & & 1066 & \\
\hline $\mathrm{R}^{2}$ & 0.75 & & 0.77 & \\
\hline Number of countries & 24 & & 24 & \\
\hline Factors & No & & Yes & \\
\hline
\end{tabular}

Note: Robust standard errors in parentheses.

${ }^{* * *} p<0.01,{ }^{* *} p<0.05,{ }^{*} p<0.1$. 
The results show that fiscal variables are important determinants of bond yields. The coefficients on the expected debt and fiscal balance are in line with previous studies. An increase in the expected fiscal deficit of 1 percent of GDP pushes up nominal bond yields by about 27 to 38 basis points, depending on the specification used. This is of a similar magnitude as in Miyajima and others (2012). It is also within the range of findings of the literature on advanced economies (where the estimated impact of a change of one percent of GDP in the fiscal deficit on interest rates ranges from 10 to 60 basis points (Laubach, 2009)). An increase in the one-year-ahead expected gross public debt-to-GDP ratio of 1 percentage point increases nominal yields by 4-5 basis points, in line with Baldacci and Kumar (2010) and in the upper range of estimates found in previous studies for advanced economies (where the estimated impact of a change of one percent of GDP in the debt ratio on interest rates ranges from 1 to 8 basis points (Haugh and others, 2009). While growth and inflation take a backseat in the first specification, once we include the factors and therefore correct for crosssectional dependence, which could lead to inefficient estimates, inflation becomes significant. Higher inflation is found to increase bond yields, in line with the previous literature (Baldacci and Kumar, 2010). Domestic growth is still not a significant determinant of bond yields in the second specification.

The second specification also produces estimates of the impact of the VIX and the expected U.S. short-term interest rate on financing costs for each of the countries included in the estimation. Coefficients vary significantly across countries. For illustrative purposes, we grouped countries into three regions: Latin America, Europe and Asia and investigated how these coefficients are linked with country specific conditions such as financial openness (measured by the Chinn and Ito (2006) index, which is now available for 2011), the strength of countries fiscal position (measured by the fiscal stress index developed by Baldacci and others, 2011) and external current account positions. Figure 7 plots the median coefficient by region against the median value of different country conditions that could be relevant in the transmission of global shocks on domestic bond yields.

Figure 7 illustrates that the coefficient on the VIX for each country is found to be closely linked to the strength of its fiscal position (as measured by the fiscal stress index) and financial sector openness. This suggests that countries with weaker fiscal fundamentals (including debt, deficits, and gross financing needs) and greater nonresident participation in their local bond markets would consequently be more susceptible to an increase in domestic bond yields if a sudden increase in global risk appetite triggered a retreat of investors to safehavens. Meanwhile the global liquidity coefficient for each country is found to be closely linked to its external current account deficit to GDP, as countries with greater public and private sector reliance on external financing would be faced with a sudden shortfall in available resources if global liquidity conditions tightened. These findings are in line with those of IMF (2013), in the context of emerging market economies' resilience to capital inflow fluctuations. This study shows that the more resilient emerging market economies have more countercyclical fiscal policy (which would imply a stronger initial fiscal position) and more stable current accounts, although capital account openness is not found to be meaningful. 


\section{Figure 7. Emerging Economies: Global Factors, Fiscal Indicators, Financial Openness, and External Current Account Deficit}
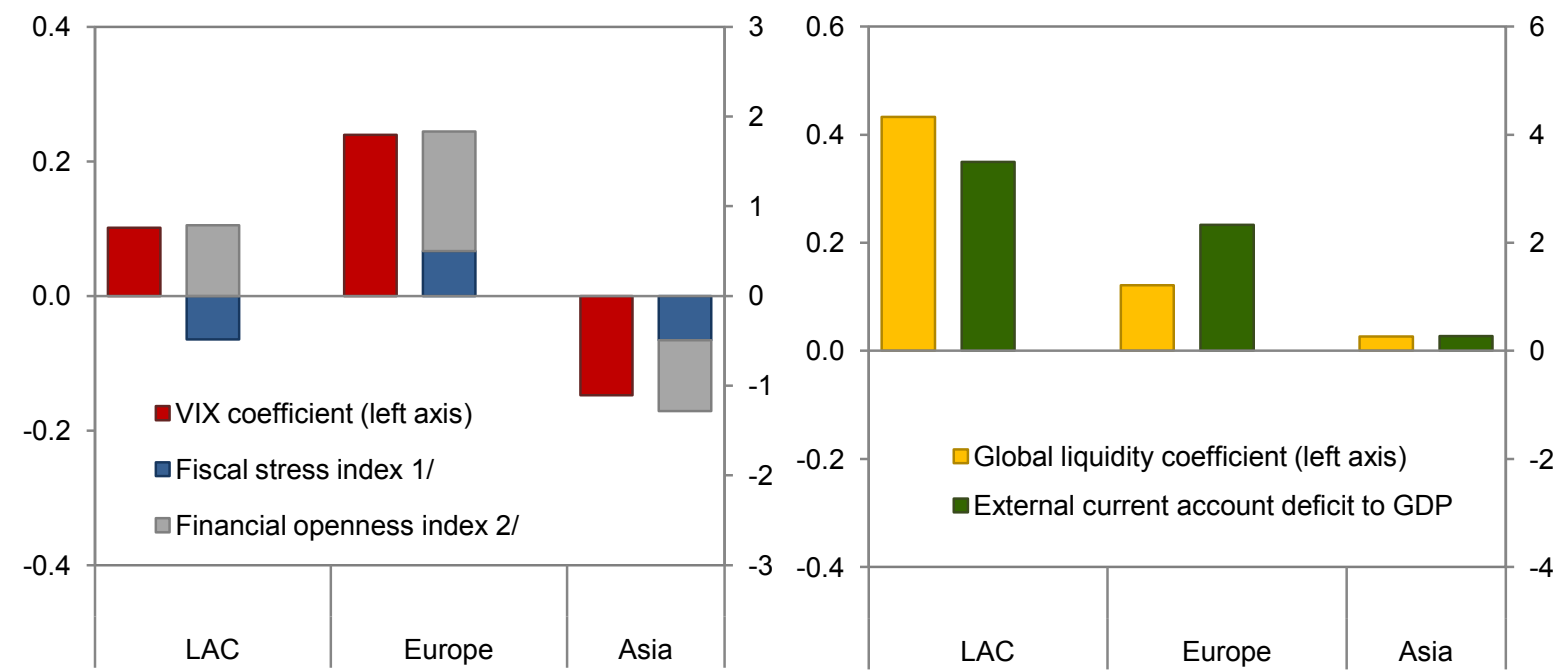

Source: Baldacci and others (2011), Chinn and Ito (2006), Bloomberg L.P., Consensus Forecast, World Economic Outlook, and authors' estimates.

Note: Bars represent median across countries in each region.

${ }^{1}$ Fiscal stress index as measures by Baldacci and others (2011), standardized. Higher values indicate greater fiscal risk.

${ }^{2}$ Financial openness index as measured by Chinn and Ito for 2011 , standardized. A higher value indicates greater capital account openness.

\section{Summary AND CONCLUSIONS}

The present paper extends Jaramillo and Weber (2013) to shed further light on the determinants of domestic bond yields in emerging markets, and the vulnerability of these economies to global shocks. This paper finds that domestic bond yields in emerging economies are heavily influenced by two international factors: global risk appetite and global liquidity. Using a novel approach, the analysis goes on to show that the vulnerability of emerging economies to these factors is not uniform but rather depends on country specific characteristics, namely fiscal fundamentals, financial sector openness and the external current account balance.

These findings suggest that financing conditions in emerging economies could deteriorate rapidly if global conditions weaken. Risks are especially high for financially more open countries with weak fiscal positions and sizeable current account deficits. These results underscore that countries should maintain a strong fiscal position to reduce their vulnerability to global shocks. In some countries, a stronger fiscal balance would also help reduce external deficits, which in turn would also improve their resilience to shifts in external conditions. For financially more open countries, key instruments to reduce vulnerability to external shocks include stronger regulatory oversight and macroprudential policies. 


\section{APPENDIX}

A. Data Sources and Differences in Coverage by Country

Table A.1. Overview of Data Sources

\begin{tabular}{|c|c|c|c|}
\hline Description & Sample & Frequency & Source \\
\hline $\begin{array}{l}\text { Long-term (typically } \\
10 \text {-year) nominal } \\
\text { domestic bond yield (in } \\
\text { percent) }\end{array}$ & $\begin{array}{l}\text { Varies by country, } \\
\text { see below }\end{array}$ & Monthly & $\begin{array}{l}\text { Bloomberg, Haver, } \\
\text { International } \\
\text { Financial Statistics } \\
\text { (IFS) }\end{array}$ \\
\hline $\begin{array}{l}\text { Interest Rate on } \\
\text { Treasury Bills (in } \\
\text { percent) }\end{array}$ & $\begin{array}{l}\text { Varies by country, } \\
\text { see below }\end{array}$ & Monthly & $\begin{array}{l}\text { Bloomberg, Haver, } \\
\text { IFS }\end{array}$ \\
\hline $\begin{array}{l}\text { Money Market Rate (in } \\
\text { percent) }\end{array}$ & 2005M1-2013M07 & Monthly & $\begin{array}{l}\text { IFS, Datastream } \\
\text { (Hungary, Vietnam) }\end{array}$ \\
\hline $\begin{array}{l}\text { Forecasts of inflation } \\
\text { (one year ahead) (in } \\
\text { percent) }\end{array}$ & 2005M1-2013M07 & Monthly & $\begin{array}{l}\text { Economist } \\
\text { Intelligence Unit } \\
(\text { EIU) }\end{array}$ \\
\hline $\begin{array}{l}\text { Forecasts of real GDP } \\
\text { growth rate (in } \\
\text { percent) }\end{array}$ & 2005M12013M07 & Monthly & EIU \\
\hline $\begin{array}{l}\text { Forecasts of public } \\
\text { debt (in percent of } \\
\text { GDP) }\end{array}$ & $\begin{array}{l}\text { 2007M3-2013M07 } \\
\text { (for most countries) }\end{array}$ & Monthly & EIU \\
\hline $\begin{array}{l}\text { Forecasts of fiscal } \\
\text { balance (in percent of } \\
\text { GDP) }\end{array}$ & $\begin{array}{l}\text { 2005M1-2013M07 } \\
\text { (for most countries) }\end{array}$ & Monthly & EIU \\
\hline $\begin{array}{l}\text { Expected U.S. 3- } \\
\text { month interest rate }\end{array}$ & 2005M1-2013M07 & Monthly & EIU \\
\hline $\begin{array}{l}\text { Expected U.S. } 10 \text { year } \\
\text { nominal bond yield }\end{array}$ & 2005M1-2013M07 & Monthly & EIU \\
\hline $\mathrm{VIX}$ & 2005M1-2013M07 & Monthly & Bloomberg \\
\hline $\begin{array}{l}\text { Forecasts of inflation } \\
\text { (one year ahead) (in } \\
\text { percent) }\end{array}$ & 2005M1-2013M07 & Monthly & $\begin{array}{l}\text { Consensus } \\
\text { Economics }\end{array}$ \\
\hline $\begin{array}{l}\text { Forecasts of real GDP } \\
\text { growth rate (in } \\
\text { percent) }\end{array}$ & 2005M1-2013M07 & Monthly & $\begin{array}{l}\text { Consensus } \\
\text { Economics }\end{array}$ \\
\hline $\begin{array}{l}\text { Forecasts of overall } \\
\text { fiscal deficit (in percent } \\
\text { of GDP) }\end{array}$ & $\begin{array}{l}\text { 2007M1-2013M07 } \\
\text { (for most countries) }\end{array}$ & Monthly & $\begin{array}{l}\text { Consensus } \\
\text { Economics }\end{array}$ \\
\hline
\end{tabular}


Table A.2 Data Sources for Domestic Long Term Bond Yields

\begin{tabular}{|c|c|c|c|c|}
\hline Country & Descriptor & $\begin{array}{l}\text { Start } \\
\text { Date** }\end{array}$ & Gaps ** & Source \\
\hline Brazil & 10 year & 2007M1 & yes & Bloomberg \\
\hline Bulgaria & 10 year & 2005M1 & no & Haver \\
\hline Chile & 10 year & 2005M1 & yes & Haver \\
\hline China & 10 year & 2006M4 & no & Bloomberg \\
\hline Colombia & 10 year & 2009M12 & no & Bloomberg \\
\hline Estonia & 10 year & $2005 \mathrm{M} 1$ & no & IFS \\
\hline Hungary & 10 year & 2005M1 & no & Bloomberg \\
\hline India & 10 year & 2005M1 & no & Bloomberg \\
\hline Indonesia & 10 year & 2005M1 & no & Bloomberg \\
\hline Latvia & 10 year & 2005M1 & no & IFS \\
\hline Lithuania & 10 year & 2005M1 & no & IFS \\
\hline Malaysia & 10 year & 2005M7 & no & Bloomberg \\
\hline Mexico & 10 year & 2005M9 & yes & Bloomberg \\
\hline Pakistan & 10 year & 2005M1 & no & Bloomberg \\
\hline Peru & 10 year & 2007M12 & no & Bloomberg \\
\hline Philippines & 10 year & 2005M1 & no & Bloomberg \\
\hline Poland & 10 year & 2005M1 & no & Bloomberg \\
\hline Romania & 10 year & 2005M4 & no & IFS \\
\hline Russia & 10 year & $2005 \mathrm{M} 3$ & no & Haver \\
\hline $\begin{array}{l}\text { South } \\
\text { Africa }\end{array}$ & 10 year & 2005M1 & no & Bloomberg \\
\hline Sri Lanka & 10 year & 2008M5 & no & Bloomberg \\
\hline Thailand & 10 year & 2005M1 & no & Bloomberg \\
\hline Turkey & 10 year & 2010M1 & no & Bloomberg \\
\hline Ukraine & 8 year & 2008M7 & yes & Bloomberg \\
\hline Venezuela & 10 year & 2005M1 & yes & IFS \\
\hline Vietnam & 10 year & 2006M7 & no & Bloomberg \\
\hline
\end{tabular}

*This is the start date in our dataset not the beginning of data availability

** This indicates that there are gaps in the data between the start date and July 2013. 
Table A.3 Treasury Bill Rates

\begin{tabular}{l|lll}
\hline Country & Start Date* & Gaps ${ }^{* *}$ & Source \\
\hline Brazil & $2005 \mathrm{M} 1$ & no & IFS \\
Bulgaria & $2005 \mathrm{M} 1$ & yes & IFS \\
Chile & $2005 \mathrm{M} 1$ & yes & Haver \\
China & No observations & & \\
Colombia & $2005 \mathrm{M} 1$ & no & Bloomberg \\
Estonia & No observations & & \\
Hungary & $2005 \mathrm{M} 1$ & no & Bloomberg \\
India & $2005 \mathrm{M} 1$ & no & Bloomberg \\
Indonesia & $2005 \mathrm{M} 1$ & yes & Bloomberg \\
Latvia & $2005 \mathrm{M} 1$ & yes & IFS \\
Lithuania & $2005 \mathrm{M} 1$ & yes & IFS \\
Malaysia & $2005 \mathrm{M} 6$ & no & Bloomberg \\
Mexico & $2005 \mathrm{M} 1$ & no & Bloomberg \\
Pakistan & $2005 \mathrm{M} 1$ & no & Bloomberg \\
Peru & $2007 \mathrm{M} 12$ & yes & Bloomberg \\
Philippines & $2005 \mathrm{M} 1$ & no & Bloomberg \\
Poland & $2005 \mathrm{M} 1$ & no & Bloomberg \\
Romania & $2005 \mathrm{M} 1$ & yes & IFS \\
Russia & No observations & & \\
South Africa & $2005 \mathrm{M} 1$ & no & Haver \\
Sri Lanka & $2005 \mathrm{M} 1$ & no & IFS \\
Thailand & $2005 \mathrm{M} 1$ & no & Bloomberg \\
Turkey & $2007 \mathrm{M} 7$ & yes & Bloomberg \\
Ukraine & $2010 \mathrm{M} 3$ & no & Bloomberg \\
Venezuela & No observations & & \\
Vietnam & $2006 \mathrm{M} 7$ & no & Bloomberg \\
\hline This &
\end{tabular}

*This is the start date in our dataset not the beginning of data availability

** This indicates that there are gaps in the data between the start and July 2013. 


\section{REFERENCES}

Akitobi, B. and T. Stratmann, 2008, "Fiscal Policy and Financial Markets," The Economic Journal, Vol. 118, pp. 1971-85.

Baldacci E. and M. Kumar, 2010, "Fiscal Deficits, Public Debt, and Sovereign Bond Yields," IMF Working Paper 10/184 (Washington: International Monetary Fund).

Baldacci, E., I. Petrova, N. Belhocine, G. Dobrescu, and S. Mazraani, 2011, “Assessing Fiscal Stress," IMF Working Paper No. 11/100.

Bandalos, D.L. and M.R. Boehm-Kaufman, 2008, "Four Common Misconceptions in Exploratory Factor Analysis", in Lance, Charles E.; Vandenberg, Robert J. Statistical and Methodological Myths and Urban Legends: Doctrine, Verity and Fable in the Organizational and Social Sciences. Taylor \& Francis. pp. 61-87.

Bank for International Settlements, 2007, "Financial Stability and Local Currency Bond Markets," Committee on the Global Financial System Papers No. 28, June.

Bank for International Settlements, 2011, “Global liquidity - Concept, Measurement and Policy Implications”, CGFS Papers No 45, November.

Bellas, D., M. Papaioannou, and I. Petrova, 2010, "Determinants of Emerging Market Sovereign Bond Spreads: Fundamentals Vs. Financial Stress," IMF Working Paper No. 10/281 (Washington: International Monetary Fund).

Burger, J., F. E. Warnock, and V. Cacdac Warnock, 2010, "Emerging Local Currency Bond Markets," NBER Working Paper No. 16249.

Cantor, R. and F. Packer, 1996, "Determinants and Impact of Sovereign Credit Ratings", FRBNY Economic Policy Review, October.

Chinn, M. D. and H. Ito, 2006,"What Matters for Financial Development? Capital Controls, Institutions, and Interactions," Journal of Development Economics, Volume 81, Issue 1(October), pp. 163-192 .

Dailami, M., P. R. Masson, and J.J. Padou, 2008, "Global Monetary Conditions Versus Country-Specific Factors in the Determination of Emerging Market Debt," Journal of International Money and Finance, Vol. 27, pp. 1325-36.

Dell'Erba, S. and S. Sola, 2011, "Fiscal Policy, Interest Rates and Risk Premia in Open Economy", Graduate Institute of International and Development Studies Working Paper 05/2013 (Geneva: The Graduate Institute).

Edwards, S., 1984, "LDC's Foreign Borrowing and Default Risk: An Empirical Investigation 1976-80," NBER Working Paper No. 1172. 
Eichengreen, B. and A. Mody, 2000, "What Explains Changing Spreads on Emerging Market Debt?", in Capital Flows and the Emerging Economies: Theory, Evidence, and Controversies, edited by S. Edwards, University of Chicago Press.

Gai, P. and N. Vause, 2006, “Measuring Investors' Risk Appetite, ” International Journal of Central Banking, Vol. 2 No. 1, (March).

Giannone, D. and M. Lenza, 2008, “The Feldstein-Horioka Fact,” ECB Working Paper Series, WP 873 (Frankfurt: European Central Bank).

Gonzalez-Rozada, M. and E. Levy-Yeyati, 2008, "Global Factors And Emerging Market Spreads," The Economic Journal, Vol. 118 (November), pp. 1917-1936.

Hartelius, K., K. Kashiwase, and L. Kodres (2008), “Emerging Market Spread Compression:Is it Real or is it Liquidity?", IMF Working Paper No. 08/10 (Washington: International Monetary Fund).

Haugh, D., P. Ollivaud, and D. Turner, 2009, "What Drives Sovereign Risk Premiums? An Analysis of Recent Evidence from the Euro Area," OECD Economics Department Working Papers No. 718.

International Monetary Fund, 2004, Global Financial Stability Report: Market Developments and Issues, April, (Washington).

International Monetary Fund, 2013, “The Yin and Yang of Capital Flow Management: Balancing Capital Inflows with Capital Outflows", World Economic Outlook: Transitions and Tensions, October (Washington: International Monetary Fund).

Jaramillo, L. and A. Weber, 2013, "Bond Yields in Emerging Economies: It Matters What State You Are In," Emerging Markets Review, Vol. 17, pp. 169-185.

Karolyi, G. A., D.T. Ng, and E. S. Prasad, 2013, “The Coming Wave,” HKIMR Working Paper No. 08/2013.

Laubach T., 2009, "New Evidence on the Interest Rate Effects of Budget Deficits and Debt," Journal of the European Economic Association, Vol. 7, No. 4, pp. 858-885.

Longstaff, F., J. Pan, L. H. Pedersen, and K. J. Singleton, 2011, "How Sovereign is Sovereign Credit Risk?” American Economic Journal: Macroeconomics, 3, pp. 75103.

McGuire, P. and M. Schrijvers, 2003, “Common Factors in Emerging Market Spreads,” BIS Quarterly Review, (December), (Basel: Bank for International Settlements).

Min, H.G., 1998, "Determinants of Emerging Market Bond Spread: Do Economic Fundamentals Matter?” World Bank Policy Research Working Paper No. 1899 
(Washington: The World Bank).

Mihaljek, D., M. Scatigna, and A. Villar, 2002, "Recent Trends in bond Markets - The Development of Bond Markets in Emerging Economies", BIS Papers Chapters 11, 112 (Basel: Bank for International Settlements).

Miyajima, K., M.S. Mohanty, and T. Chan, 2012, "Emerging Market Local Currency Bonds: Diversification and Stability," BIS Working Papers, No. 391.

Pan, J., and K.J. Singleton, 2008, "Default and Recovery Implicit in the Term Structure of Sovereign CDS Spreads,” Journal of Finance, 63(5), pp. 2345-84.

Peiris, S.J., 2010, “Foreign Participation in Emerging Markets’ Local Currency Bond Markets,” IMF Working Paper 10/88 (Washington: International Monetary Fund).

Pesaran, M. H., 2004, "General Diagnostic Tests for Cross Section Dependence in Panels," Cambridge Working Papers in Economics No. 0435 (Cambridge: Cambridge University).

— 2006, "Estimation and Inference in Large Heterogeneous Panels With A Multifactor Error Structure," Econometrica, Vol. 74, No. 4, pp. 967-1012.

Rigobon, R., and B. Sack, 2003, "Measuring the Response of Monetary Policy to the Stock Market," Quarterly Journal of Economics, 118, 639-669.

Rowland, P. and J. L. Torres, 2004, "Determinants of Spread and Creditworthiness for Emerging Market Sovereign Debt: A Panel Data Study," Borradores de Economia 295, Banco de la Republica de Colombia.

Shin, H.S., and T. Adrian, 2010, "Liquidity and Leverage," Journal of Financial Intermediation, 19 , no. 3, pp. 418-37

Sgherri, S. and E. Zoli, 2009, "Euro Area Sovereign Risk During the Crisis," IMF Working Paper No. 09/222 (Washington: International Monetary Fund)

Vargas, H., A. Gonzalez, and I. Lozano, 2012, "Macroeconomic Effects of Structural Fiscal Policy Changes in Colombia,” BIS Papers No. 67.

Velicer, W. F., and D. N. Jackson, 1990, "Component Analysis Versus Common FactorAnalysis - Some Further Observations," Multivariate Behavioral Research, 25(1), pp. 97-114.

Weber, A., 2012, "Stock-Flow Adjustments and Fiscal Transparency: A Cross-Country Comparison," IMF Working Paper 12/39 (Washington: International Monetary Fund). 